\title{
THE CULTURE DEBATE
}

Identity is always 'in process', always 'being formed'. It is 'dynamic and fluid as individuals continuously relate to institutions, communities and other individuals'. ${ }^{1}$ David Matsumoto and Linda Juang argued that cultural and personal identity are shaped to a large extent by our culture and the environment in which we live. ${ }^{2}$ As we grow up our cultural setting tends to mould our sense of self in ways that 'make sense' within that cultural setting. It follows that different cultures produce different self-concepts in their members, and in turn these different concepts influence all other aspects of individual behaviour. Even what people actually mean and understand as the 'self' differs dramatically from one culture to another. Sometimes, while living within one's cultural environment (family and ethnic and religious community settings), people can be influenced by another culture (the wider society's schools, workplaces and institutions) depending on their geographical location and circumstances.

In a diaspora setting, the children of first-generation Muslims (like many other immigrants) go through enculturation and acculturation processes. Enculturation generally refers to the process by which individuals learn and adopt the ways and manners of their respective cultures. ${ }^{3}$ Matsumoto and Juang stated that enculturation is related to ethnic identity development, whereas acculturation entails adopting a second culture. ${ }^{4}$ In other words, enculturation is first-culture learning and acculturation is subsequent-culture learning. In this context, first-culture learning involves acquiring one's mother tongue, and adopting traditional dress, food, music and dance, and religion. The religion of Muslim youths is denoted by their names, eating and drinking habits, and adherence to religious rituals. Matsumoto and Juang observed that enculturation (into one's ethnic culture) occurs through parenting styles, child-rearing practices, peer groups, day care, the education system and religious institutions. Acculturation occurs through involvement in the exter- 
nal environment. ${ }^{5}$ For example, youths acquire education, English-language skills, and knowledge of music and sport from their participation in the wider society.

Some scholars have noted that in the processes of enculturation and acculturation two fundamentally different senses of self can impact on one's identity. For example, on the one hand, there may be a non-western understanding of self that is 'collectivistic', and on the other hand, there could be a western understanding of self that is 'individualistic' ${ }^{6}$ In the non-western 'collectivistic' context, the individual is viewed as inherently connected to and interdependent on others; for example, individuals will respect their family's decision rather than be adamant about their own choices. This 'collectivistic self' of young Muslims is revealed later in the chapter in the discussion of women and Muslim youth. In the 'individualistic' context, a person is the sole maker of his or her destiny. That said, it is important to recognise that these cultural models are only tendencies, and it is entirely possible for an individual to embrace both an individualistic and a collectivistic stance as precursors to acquiring bicultural skills.

Studies by Alberto Melucci and Gary Gregg demonstrate that bicultural individuals can shift identities between the cultural frames of both ingroups and outgroups with relative ease. ${ }^{7}$ That is, a bicultural identity caters for emotional tensions and creates a sense of adaptability. ${ }^{8}$ Melucci observed that a (bicultural) identity of self becomes a dynamic system defined by recognisable opportunities and constraints. ${ }^{9}$ Identity is both a system and a process, because the field is defined by recognisable opportunities and is simultaneously able to intervene to act upon and restructure itself. Two crucial and perplexing questions arise here: the continuity of the self and the boundaries of the self. The question is one of deciding where the subject of action begins and where it ends and how a person is likely to adapt to a new culture. For example, a Muslim may socialise with his non-Muslim colleagues at his workplace, drink tea with them but refrain from drinking alcohol (which is forbidden in Islam). Melucci noted that an individual's (bicultural) identity floats within the primary bonds of belonging, like kinship or local and geographical ties (family, community, country of origin and place of residence). ${ }^{10}$ In other words, bicultural identity is flexible and may move through both independent and interdependent collective stances, which is again possible when an individual has a firm grip in both cultures through education, sport, and dialogue and communication.

In this chapter I briefly examine the religious, economic and social settings of young Muslims in America. Firstly, I discuss the different ideologies within the Islamic community, including the placement of minorities within the Muslim majority group such as Shicite and Sunni relations in America. Secondly, I examine the economic placement of the participants of this study. Thirdly, I examine women's place within the Muslim community. Fourthly, I evaluate the male youths'/young adults' social issues within the broader 
Islamic community. Finally, I discuss the implications of homeschooling in the youths' upbringing.

\section{Islam in America}

The religious affiliations of the 379 interviewees were: Sunni: 358, Shia: 18, Nation of Islam (NOI): 3 . The two branches of Islam, Sunni and Shicism, are explained below. Some Sunni and Shia Muslims consider the NOI to be an offshoot of Islam, but I will attempt to explain the NOI's place in the broader Islamic community.

The word Sunni in Arabic comes from the term ablal-sunnah wa'l-jama'ah, 'people who followed the teachings of Prophet Muhammad (PBUH)' and worldwide they are in the majority. Shi' ism comes from the Arabic term shi'at 'Ali, meaning 'partisans of Prophet Ali', ibn Abi Talib, son-in-law and cousin of Prophet Muhammad (PBUH). The major point of contention between Sunnism and Shi'ism is who succeeded the Prophet Muhammad (PBUH) as the 'rightly guided' caliph of Islam. ${ }^{11}$ After the death of Prophet Muhammad (PBUH), while Ali and other family members were burying him, the rest of the Muslim community gathered in Medina and chose Abu Bakr as the Prophet's successor, not in his prophetic function but as ruler of the newly established Islamic community. He was thereby given the title of khalifah rasul Allah, or the vice-regent or the Messenger of God, from which comes the title 'caliph'. A number of people thought that Ali should have become Prophet Muhammad's successor and rallied around him, forming the first nucleus of Shi ism (or Shi' ites). Ali himself refused to oppose Abu Bakr and in fact worked closely with him and his two successors, Umar and Uthman, until he himself became the fourth of the 'rightly guided' caliphs of Sunni Islam. ${ }^{12}$

The followers of Sunnism are divided into four schools of law (fiqh, or jurisprudence): Hanafi, Maliki, Shafi'i and Hanbali. Today the Hanafi school has the largest number of followers in the Sunni world. Malikism is based mostly on the practice of Medina and is very conservative in its approach to the fiqh. The Shafi' $i$ school is followed by some Arabs, particularly the Egyptians. The Hanbali School adheres to a very strict interpretation of the shariab code. Wahhabism and Salafism, which are dominant in Saudi Arabia, are really offshoots of Hanbalism. Both Wahhabism and Salafism are very much opposed by the vast majority of Sunnis and also by Shicites. ${ }^{13}$

In contrast to the traditionalist branches of Islam, the Wahhabis and Salafis reject the importance of juridical schools and advocate a direct relation to the revealed text of the Quran. The puritanical Salafi line of thought prevails in the Arabian peninsula and also in Syria, Jordan and Egypt. The main difference between Salafi and Wahhabi ideology is the difference in audience. That is, some Muslims prefer the term 'Salafi' while some prefer 'Wahhabi', but in reality their adherents follow the same puritanical ideology. ${ }^{14}$ Also the Salafis 
hold certain opinions on the issue of visiting graves. They believe that Prophet Muhammad (PBUH) encouraged his companions to visit graveyards, because it is something that can remind Muslims of death and make them think about preparing for it by doing good deeds. The Salafis believe that Prophet Muhammad (PBUH) gave stern warnings about not falling into excess in this regard, because the end result is to associate dead persons with Allah and that negates one's Islam. ${ }^{15}$ The Wahhabis and Salafis denounce the celebration of Eid-e-Milad-un $\mathrm{Nabi}$ (the birthday of Prophet Muhammad (PBUH)) and Sufism.

Sufism is a mystical movement that preaches tolerance and recognition of the commonality between all religions through poetry, lyrics, music, songs and chanting of different kinds and in many dialects. The Sufi sect allows an individual to join or leave a group at will, sometimes even without the requirement to be a Muslim. ${ }^{16}$ Most Sufis belong to the Hanafi school of law and, of course, Sufism differs from the conservative Wahhabi and Salafi ideologies. Sufi Muslims believe that by nature Islam is a religion open to people of every race. The Sufi saint Bayazid al-Bistami said, 'Sufis, in general, seek God's mercy for everyone, not solely Muslims. ${ }^{17}$

The other major branch of Islam, Shicism, follows all the four Sunni schools of law, together with one additional school called the Ja'fari. ${ }^{18}$ The difference between the Sunni School of Law and the Ja'fari is minor, especially when it comes to the practice of rites (the five pillars of Islam). In certain fields, such as the laws of inheritance or the legality of temporary marriage, there are, however, notable differences. ${ }^{19}$ The Shicites believe that the Wahhabi, Salafi and Tablighi movements emerged from the Sunni school. ${ }^{20}$ The Tablighi Jamaat, initiated in the Indian subcontinent, claims to be a peaceful and apolitical revivalist movement that promotes Islamic consciousness among Muslims. ${ }^{21}$

In America Shicites form a minority within the broader Islamic community; however, they constitute a higher proportion than the 13 per cent they represent worldwide: it is estimated that 20 per cent of American Muslims are Shicites. ${ }^{22}$ In this study, out of 379 participants, only eighteen (about 5 per cent) were Shicites. Some Shi ites feel that they are discriminated against by Sunnis. For example, in 1999 Frankie Cancel, a Hispanic convert to Shi'ism, complained that the Sunni chaplain at Fishkill correctional centre in New York insulted Shi ites on a regular basis, and that the Islamic services provided within the facility were only affiliated to Sunnism. ${ }^{23}$

After the US invasion of Iraq in 2003, the sectarian clashes in Iraq had repercussions in America. In 2006 during the Muharram procession through the streets of Manhattan, Shi ites were confronted by some Sunni protestors who denounced the ritual and distributed fliers condemning the Shicites as heretics and unbelievers. For several years, Shi ites had marched through the streets of Manhattan in the month of Muharram using self-flagellation and chest beating as part of their ritual, so it was not something new on the streets. 
Also, in 2006, after the execution of the former Iraqi Sunni ruler Saddam Hussein, three mosques and some Shi ite businesses in Dearborn were vandalised. Sunni Muslims in Dearborn were alleged to have carried out the attacks, though no one was arrested. ${ }^{24}$ In my study in 2010 a Shica leader in Florida expressed his concerns that their institutions were vulnerable to Wahhabi attacks (interview, May 2010). ${ }^{25}$

In this study three interviewees affiliated their beliefs with the NOI. The NOI has been controversial since its inception. Its initial leaders (for example Elijah Muhammad) placed emphasis on black superiority and separatism. They believed that mainstream (white) Americans were responsible for the destitute conditions of the black people. ${ }^{26}$ But mainstream Muslims (Sunnis and Shi'as alike) believe that all people are equal before Allah. The NOI teaching that 'whites' have descended from the 'devil' ${ }^{\prime 2}$ contradicts the Muslim concept of egalitarianism. The late NOI leader Malcolm X was opposed to integration with 'white' Americans until he performed his hajj in 1964. At the haji, Malcolm X realised that people of all races can perform the pilgrimage without any racial bias, departed from his separatist ideology and thereafter preached equality. His son Wallace Muhammad also encouraged the belief that 'whites' should be considered fully human and even encouraged them to become members of the NOI. ${ }^{28}$

When I was writing this book, Louis Farrakhan was the leader of NOI. Farrakhan generally followed the black separatist ideology of Elijah Muhammad. During my fieldwork, I visited a NOI mosque and found that it was not open to 'white' people. The minister of the mosque, Brother Ahmet, explained that their mosque served as a healing clinic for black youth who had been persecuted by 'whites', so they wanted to avoid the painful reminder of oppression (interview, New York, January 2010). Brother Ahmet shared his life story and involvement with the NOI:

My childhood as a young black man growing up in America was very similar to what we see today. Born to a young mother, and no father around, and born into poverty.

Yes, I was surrounded by crimes, drugs, you name it. The same scenario that many of our young men live today. I was labelled a problem child in school. But many of the problems I had in school came because of the problems I had at home. By the time I was twelve years of age, I was kicked out of the school...

Sports were definitely a great part of my life. I also found out that I had speaking skills and began to get involved in drama and other things of that nature. But it wasn't until [then] I had an opportunity to discover gifts, skills, talents and abilities. But the Nation [of Islam] really pulled the complete cover off of gifts, skills, talents and abilities for me.

Brother Ahmet said that with the help of the NOI he later managed to complete his education. Jane Smith observed that Louis Farrakhan's NOI was 
controversial but it has provided important social and community services to the marginalised community, particularly to black and Hispanic youths. The US government also supports its drugs and AIDs programs. ${ }^{29}$

\section{The economic position of Muslims}

In my previous studies on Muslims in Australia and the UK, I was able to evaluate their labour market status from official census data. But in the United States official census data on the basis of religion is not available. So for this section I had to seek other sources to gauge the economic position of Muslims in America. Later, I evaluate the economic status of the participants of this study.

Jamillah Karim discussed the class disparities among different ethnic and racial groups in the USA. She observed that of all the ethnic and racial groups, African Americans have been the most disadvantaged. For example, in 2003, African Americans had the lowest median household income: $\$ 33,500$, compared to Hispanics $(\$ 37,600)$, whites $(\$ 52,000)$ and Asians $(\$ 64,000) .{ }^{30}$ Anna Bowers observed that the majority of Muslim converts in America, both in the United States overall and in its prisons, are African Americans. Nationally, 49 per cent of prison inmates are African American, compared to 13 per cent of the overall population. ${ }^{31}$ The high percentage of African Americans in prison can be attributed to poverty, lack of education and the institutional racism associated with the war on drugs. ${ }^{32}$

In 2009, a Gallup poll found that the economic disparity among Muslims reflected racial income differences in the country. For example, while 44 per cent of Muslim Asian Americans had a monthly household income of \$5,000 or more, only 17 per cent of Muslim African Americans reported such an income. ${ }^{33}$ The poll also found that young adult Muslims (aged 18-29) make up a far larger percentage ( 36 per cent) of their religious group than their counterparts in the general population (18 per cent), but Muslim Americans in that age group were particularly discontented with both their jobs and their communities.

In 2011, the Pew Research Center's survey found that about 26 per cent of American Muslims were college graduates compared to 28 per cent of the total population, and about 14 per cent of American Muslims were school dropouts compared to 13 per cent of the total population. However, Muslims born in America were more likely than the total population to have graduated from high schools. About 26 per cent of American Muslims were still enrolled in colleges or universities compared to 13 per cent of the total population. ${ }^{34}$

In the labour market, the Pew Research Center's survey found that in 2011 about 41 per cent of American Muslims had full-time employment compared to 45 per cent of the total population. In addition to this about 18 per cent of US Muslims had part-time employment and about 20 per cent were 
self-employed or small business owners. Underemployment was, however, more common among Muslims compared to the total population. About 29 per cent were either unemployed or working part-time but preferring to have full-time employment, compared with 20 per cent of adults nationwide. Underemployment was particularly widespread among Muslim adults aged under thirty. ${ }^{35}$

In 2011, the annual household income of 14 per cent of American Muslims was $\$ 100,000$ or more compared to 16 per cent of the total population; 40 per cent of American Muslims had annual household incomes of between $\$ 30,000$ and $\$ 100,000$ compared with 48 per cent of the total population; and 45 per cent of American Muslims had annual household incomes of less than $\$ 30,000$ compared to 36 per cent of the total population. ${ }^{36}$ The Pew Research Center observed that the average annual income of Muslim Americans had declined since its last survey in 2007, when the proportion of Muslim Americans (35 per cent) and the total population (33 per cent) earning under $\$ 30,000$ was similar. This decline indicated that Muslims were intensely affected by the 'bursting of the housing market bubble in 2006 and the recession that followed from late 2007 to mid-2009'. ${ }^{37}$ In the next section I examine the economic placement of the participants of this study (see Table 2.1 and Table 2.2).

The employment statuses can be defined as follows:

- 'Employed, category 1' includes skilled/tertiary-educated people such as university academics, educators, physicians, pharmacists, engineers, teachers, researchers, lawyers and consultants.

- 'Employed, category 2' (mostly non-professionals) ${ }^{38}$ includes religious leaders, community workers, imams, religious teachers in Sunday schools, clerical workers, administrative staff, child care workers, nurses, physical

Table 2.1 Employment status of students' parents (student age group: 15-30)

\begin{tabular}{lcc}
\hline Employment status & Father & Mother \\
\hline Employed, category 1 & 85 & 22 \\
Employed, category 2 & 90 & 53 \\
Self-employed & 77 & 7 \\
Unemployed & 17 & 1 \\
Incapacitated & 5 & 0 \\
Retired & 1 & 1 \\
Student & 2 & 4 \\
Homemakers/'stay-at-home mums' & 0 & 200 \\
Other & 13 & 2 \\
Total & 290 & 290 \\
\hline
\end{tabular}


Table 2.2 Employment status of 'non-student' participants (age group: 21 and over)

\begin{tabular}{lcc}
\hline Employment status & Male & Female \\
\hline Employed, category 1 & 23 & 26 \\
Employed, category 2 & 10 & 13 \\
Self-employed & 7 & 2 \\
Unemployed & 0 & 0 \\
Incapacitated & 0 & 0 \\
Retired & 1 & 0 \\
Student & 0 & 1 \\
Homemakers/'stay-at-home mums' & 0 & 5 \\
Other & 0 & 1 \\
Total & 41 & 48 \\
\hline
\end{tabular}

therapists, dental assistants, security officers, mechanics, salespeople, chefs, waiters, cab drivers, construction workers, factory workers, carpenters and handypeople. Some people in category 2 have overseas university degrees but these may not have been recognised in the USA.

- 'Self-employed' includes people engaged in small businesses, shopkeepers, petrol station owners, contractors, estate agents, and owners of big businesses such as construction companies.

- 'Unemployed' includes members of the labour force (15-64 years) not at work. In this category some people have been laid off from their previous jobs, or are looking for a job.

- 'Incapacitated' includes people who cannot work for health reasons.

- 'Retired' includes people over sixty-five.

- 'Student' includes mature students (aged over 30) studying in colleges or universities.

- 'Homemakers' is for housewives or, as the participants said their mothers were, 'stay-at-home mums'.

- 'Other' includes overseas students, single parents, step-parents, divorced people, the deceased and fathers working overseas.

\section{Analysis}

Table 2.1 shows the economic situation of the parents of 290 students. Out of 290 fathers, 252 (about 87 per cent, including 29 per cent professionals) were employed. Out of 290 mothers, eighty-two ( 28 per cent, including 8 per cent professionals) were employed. Seventeen fathers ( 6 per cent) were unemployed/looking for work, while only one mother was looking for work. Five fathers (2 per cent) could not work because of health issues. The number of stay-at-home mums was 200 , which was about 70 per cent. 
Table 2.2 shows the adult 'non-student' participant (over 21) workforce status. Out of forty-one adult male participants, forty (about 98 per cent, including 56 per cent professionals) were employed, and out of forty-eight female participants, forty-one (about 85 per cent) were employed. None of the participants in Table 2.2 were unemployed or looking for jobs. Only five women (about 10 per cent) were 'stay-at-home mums'. In 'employed, category 1', out of forty-nine participants only eighteen (twelve male, six female) held professional positions in the wider society, for example, in public schools, state government and the private sector. The majority (thirty-one participants, mostly educators) held positions in Islamic institutions. A few of them said that although they had higher university degrees (for example, PhDs) they had not been successful in securing relevant positions in mainstream American institutions. And all participants (with the exception of two administrative officers) in 'employed, category 2' held positions in Islamic institutions. Some participants in this category said that they had not been successful in securing positions in mainstream American institutions (the women thought that perhaps this was because they wore the hijab).

However, both tables show a large number of stay-at-home mums (205 mostly first-generation women), which reveals that either educated mothers preferred to stay at home and look after their children, or mothers have insufficient education or desire to pursue a career. In some cases, Muslim women are discouraged from taking an outside role by their husband or members of their extended family. I did not ask the participants about the qualifications of their parents, but one second-generation female participant, Aysegül (15, US born, of Turkish background), said that she wanted to pursue a career and pointed out that in her family women's higher education was not a priority:

And I want, insh'Allah, I'm praying to God, I want to be a lawyer. I want to be the first educated girl in my family. 'Cos my cousins and everybody, they dropped out of high school, they all got married. There's not really anybody, you know, from my mom's side well educated. (Interview, New York, February 2010)

In this study, some second-generation young Muslims who were educated in America and looking for jobs said that they had difficulties finding work. Some anecdotes follow.

\section{Difficulties in the job market}

A female participant, Bushra (21, US-born student of Bangladeshi origin, national identity: Bangladeshi Muslim American), believed that her Islamic identity, revealed by her hijab, deprived her of employment: 
Basically, I've been applying to a lot of jobs, especially after my father lost his job last fall. So I've been applying to a lot of fast food places so I could help with payments and bills with my parents. And a fast food shop called me back for an interview, and told me to go in to speak with one of the managers.

The manager just asked me general questions about myself ... Then she asked me about my hijab, 'Do you have to wear that thing on your head?' I replied, 'My hijab, I do, I have to wear my hijab all the time.' And she said, 'Oh,' and she had a little weird look on her face. I asked her, 'Is that a problem?' And she said, 'You can't wear that on the job.' I said, 'Why?' She said, 'Our fast food shop has certain terms and policies that may prohibit that.' I asked her, 'What are these terms and policies?' She said, 'All employees are required to wear a uniform cap while they work.' I said, 'I have no problem with that. I can wear a cap on top of my hijab, that's perfectly fine.' (Interview, Michigan, May 2010)

Bushra said that she was told the manager would make her decision in the next couple of days. But Bushra heard nothing from the manager so she called a week later to find out about the job. Bushra found that the manager had decided to hire someone else, so she asked the manager, 'Was there something wrong with my interviewing, or social skills?' Then she asked, 'Did my headscarf have anything to do with it?' The manager replied, 'No, it didn't.' Bushra then told the manager that she felt discriminated against and the manager apparently became very defensive. Bushra said:

Muslim women may be questioned for wearing a hijab, and that is not fair. That is not fair, because she may be an American citizen, born here. So that is invading her civil liberties and the First Amendment to her rights.

Another female participant, Zohra (30, Palestinian background, national identity: Muslim American), who was born and raised in the United States, also believed that she was discriminated against for wearing a hijab. Zohra had a teaching degree from an American university but was not able to get a job. Zohra shared her viewpoint:

It's very prejudiced ... I f fight for jobs. I want a part-time job and it's very difficult to find a job with the bijab, to be honest. They say it's not the hijab, it's the qualifications, but when you know somebody else was hired and they have only a high school degree when, well, you have three degrees, you say, 'Hey, you know, something's wrong here.' So there is a lot of prejudice. Even though people don't like to admit it, there is a lot of prejudice around. (Interview, New York, February 2010)

In Maryland I met a Muslim woman who said she wears a hijab at her workplace and this works positively in her work environment because her company has endorsed diversity. But this was an exception. 
It is difficult to pin down why, in some cases, the hijab is still a marker of the 'other'. Sometimes, customer-related jobs do not approve any kind of dress other than their specified (western) dress code. Then when a Muslim employee decides to wear a hijab in the workplace, her male colleagues may perceive that she wants to remain different, so they are hesitant to interact with her. Differential treatment of the 'other' - based on dress - could be discrimination, ${ }^{39}$ but it is just as likely to be a matter of social awkwardness.

It appears that some young Muslim men also face resistance in the US labour market. In 2010 a couple of final year engineering students, Ulfat and Dawood, expressed their concerns that there were no jobs for them in the United States. As Ulfat (US born of Guyanese background, national identity: 'Muslim only') said, 'Every year a lot of engineers are graduating but there are no jobs' (interview, Florida, March 2010). Dawood (26, overseas born of Lebanese origin, national identity: Lebanese) was also frustrated because of his unemployment: 'When I came to this country in 2006, there was a recession, so I didn't find a good job, a full-time job from the beginning till now' (interview, Michigan, May 2010). So he commenced postgraduate studies. Zainab (30, US born of Palestinian background) said that her brother was experiencing discrimination in his job because he was an Arab:

My brother tried so many times to get a promotion but he was denied many times to go into a different unit ... Why is he being pushed back? Why is he just being thrown in the dumps just to translate, okay, when the occasional Arab comes in? (Interview, New York, January 2010)

During the recession in America (since 2007), it has been difficult even for those participants born, raised and educated in the US. For those overseas born, with overseas degrees, finding an appropriate job has been especially difficult because in some cases their overseas degrees are not recognised, and their poor English skills are a factor. But, as Zainab observed, there could be a subtle barrier in the way of promotion for Arabs actually in the workforce even though they were born and educated in the United States. ${ }^{40}$

\section{Muslim women}

Over the last few years a few Muslim women in America have defied Muslim men's traditional norms. In 2003, for example, the Indian-born journalist Asra Nomani went into a mosque in West Virginia using the men's rather than the women's entrance. She sat down in the men's section and, when asked to leave, she refused. Her story generated a great deal of media coverage over a short period. Later, Nomani wrote a book, Standing Alone at Mecca. ${ }^{41}$ In 2004, the African American scholar-activist Amina Wadud became the first woman to lead a mixed-gender congregation and give the sermon at a Friday 
prayer service. Several mosques refused her request to host their services, and finally she held an Islamic service at the Synod House of the Cathedral of St John the Divine in New York. The event generated an international debate on whether Wadud's actions were Islamically acceptable. ${ }^{42}$ There have been other occasions when women have expressed dissatisfaction with the way they were treated at a mosque. In 2008, when a Muslim woman and her non-Muslim mother wanted to enter a mosque in Colorado, they were told they would not be allowed to pray there because there were no other women in the mosque. ${ }^{43}$

Upon reflecting on the Asra Nomani, Amina Wadud and Colorado mosque issues, I believe that dialogue is needed between Muslim men and women on mosque-related and other matters. As discussed earlier (see Introduction), I lived in Muslim countries for many years. I have found that most of them are steeped in the patriarchal model where gender segregation and differentiation is emphasised. Women are expected to exhibit subservient behaviour, such as to be modest and kind, obey their husbands, and bring up the children. Men are expected to exhibit masculinity by being strong and tough and bearing primary financial responsibility for their families. ${ }^{44}$ Many women in those countries have become used to and are accepting of such norms. Thus, even in America - where women in general enjoy near-equal status with men in most matters - Nomani's and Wadud's actions to break with traditional practices in the mosques brought objections from many first-generation Muslim women.

Nomani was born in India and migrated to the USA at an early age. Being raised in the USA, she probably acculturated into the 'American way of life'. Anyway, Nomani was not willing to comply with the traditional practice in the mosque of women having a separate space for prayers. Likewise, as an African American convert, Amina Wadud was not happy with traditional practice in the mosques. Incidentally, in many Muslim countries women do not attend mosques; they pray at home. But when such women immigrate to a western country they may want to attend mosques for social and cultural reasons, and may wish that their children should also attend mosques. Yet it is reasonable to predict that most of these Muslim women would prefer to have a separate space for themselves in the mosques for their privacy and to comply with their religious beliefs about maintaining distance from men (other than their spouses). ${ }^{45}$ As for the Colorado mosque issue, sometimes men discourage women from attending mosque on their own (without any male relatives) for security reasons and because of fear of rape or assault.

In this study, a young girl (16) complained that men in mosques can be very rude to women (interview, New York, November 2009). Of course, some Muslim men still display patriarchal, masculine attitudes in mosques, and this behaviour is objectionable because it gives younger people who are being raised in the western world a negative perception of their religion. In the next section I discuss the cultural complexities that young Muslim women face as they are raised in America. 


\section{Cultural restrictions}

Yvonne Haddad and Nazli Kibria observed that in the United States some girls face cultural restrictions from their parents, who are mostly first-generation Muslims. ${ }^{46}$ These restrictions may come from the mother as well as the father. For example, a Bangladeshi mother would expect her daughter to live the lifestyle she had in Bangladesh, which would restrict the daughter from integrating with mainstream Americans. Thus the daughter would not be allowed to go to parties or socialise with non-Muslim friends.

Of course, cultural restrictions are not confined to immigrant families. For example, an African American woman, Mehnaz, aged twenty-two, who identified herself as 'only Muslim', said, 'My Dad converted [to Islam] when he was eighteen and my Mom when she was thirteen, she took her shahada [converted to Islam].' Mehnaz had a bicultural upbringing:

I played basketball, soccer, softball; my favourite sport was swimming, though. I was on the swim team in my high school and I was fast. I absolutely love swimming, so yeah, I'm interested in playing sports, but as far as watching sports, no, I change the channel. (Interview, Maryland, April 2010)

Mehnaz also liked music. She said, 'I have Michael Jackson all over my iPod and absolutely love it and I miss him and I wish he would have got some more music out.' Her 'Muslim self' made her realise that she should read Islamic books:

I used to read novels, but I realised that I was spending too much time reading those and not enough time reading Islamic books, so right now I'm reading a book called The Pillars of Islam and Imam and it's just basics of Islam. Because sometimes, even born and raised Muslim, I had to go back to the basics to remind myself.

Mehnaz was a single parent who worked in an Islamic institution. It is normally expected that cultural restrictions are imposed in a patriarchal family where the father is the figurehead. But in this case, Mehnaz, as a mother, was protective of her daughter and she feared that outside influences would impact on her child. Mehnaz said, 'I can't stand the TV now because everything is sex, violence, women half naked, it's too open now with everything.' She expressed further concerns:

It's almost like there's no sense of censorship any more. Even children's channels show all kind of things that they shouldn't be seeing. Like I said, it's scary to think my daughter is growing up in this country with all these things being promoted as acceptable. How can you feel comfortable wearing hijab when everybody around you is wearing nothing and they're confident with it and look good and everybody's 
telling them 'Your body looks good, you want to shake this way, your body looks good when it does that, get this surgery to make you look better', you know?

Sometimes immigrant parents who have similar cultural fears to Mehnaz send their children to their country of origin for a few years to keep them within their cultural boundaries. Mehnaz, being an African American parent, did not have such a choice.

\section{Cultural contrasts}

In this study many of the second-generation participants spoke of the cultural contrast between their host country and their country of origin. For example, US-born Sadiqah, of Palestinian-Jordanian background (23, national identity: Arab Muslim), spoke of her cultural experience in Jordan:

Actually for four years my father took us back to Jordan to learn Arabic, so my elementary education was in Jordan and then we moved here and he was really afraid of putting us into public school, so he put us into the Islamic school for a couple of years and then high school was in public school. (Interview, Florida, March 2010)

After her college degree, Sadiqah was again sent to Jordan for further studies, and she was expected to marry an Arab while she was there. At the time of interview, Sadiqah was struggling with cultural issues:

Well, in the beginning, I used to say I was more Arab or more Muslim, but once I moved overseas I realised how American I really was. I don't have the traditional Arab mentality ... I'm very open minded. I'm very understanding. I feel they have cultural niches over there where they have to just be a religious group, a liberal group, there is no moderation at all and over here I think it's just so open to accepting anything and everything.

Though Sadiqah identified herself as an Arab Muslim, she was at the same time distancing herself from that identity. She took pride in her western/American values, saying 'we the Americans' are 'open minded', 'very understanding', and she believed that 'they, the Arabs' are 'liberal but at the same time they're very close minded'. Sadiqah explained this by saying, 'Liberal in the sense where they adopt western dress, but not the etiquette of the West and not the understanding of other groups.' She continued with her observations:

I've found here in the West, people are not as selfish when it comes to public domain. Over there they'll throw something on the street; they don't care. If they hit you while they're walking, they don't look back and say 'Excuse me', they just keep 
going. Over here there's a lot of social etiquette where they'll be 'Oh, please excuse me' or 'I'm sorry'. Over there it's very hard to find that.

Sadiqah's depiction is not exclusive to the Arab world; it is a typical characterisation of any developing country such as Bangladesh or Pakistan.

New immigrants to the western world, however, are also bothered by crosscultural issues. For example, a recent immigrant to America, Muneera (16, Yemeni background, national identity: Yemeni American), was shocked at the way American Muslim Arabs dressed, and the way they spoke and interacted with the opposite gender (interview, Michigan, May 2010). Muneera had been used to seeing Yemeni men wearing jambiyas (traditional daggers), and women in the abaya and the niqab, so she commented, 'But here they wear pants and their scarves.' Regarding language, Muneera said, 'Here they mix it up, English Arabic, I get confused ... I talk fast [fluent] Arabic, but here they are slow and stop [not fluent].' Muneera was critical of 'too much freedom' in America, and compared her 'home' (Yemeni) culture to American culture:

Over here too much freedom like boyfriend, girlfriend and stuff . . . they go out and they haven't married and a lot of girls, they get kids. In our country we marry when we are small, from fifteen years and up, and we don't go outside dating them [before marriage].

Muneera spoke further of her 'home' culture:

For us, 'cos in Yemen, when we [the girls] walk I had to look down and walk ... We cannot talk to boys, but talk to them about important things, for the homework, but there can be no eye contact ... Like if your grandmother saw you talking with a man there would be trouble ... If the girls did something wrong, it will bring shame to their family.

Muneera also spoke of the extreme side of her 'home' culture:

If you love someone, you should go tell your Mom, then your Mom focuses. Asking you for the boy, sometimes if they catch them, they get killed too and they brought shame to their Dad ... The boy because he take the girl and there are two that are dead. They say that he stole that girl and he took her $[$ sic].

Muneera was indicating that lovers might become victims of honour killings if their relationship was not approved by their parents. When I asked if young lovers got any protection from the police or government, Muneera replied, 'They don't care. It's like family matter.' In America Muneera maintains her cultural practice but is slowly acculturating into the 'American way', as later reflected in her statement that she does not keep her head down as she used to 
do in Yemen. In an earlier conversation Muneera mentioned that her identity was 'Yemeni American':

Over here I'd be focussed and I don't talk to them [the boys]. I walk away from them. I don't get my head down like this. I make myself proud of myself that I'm wearing my scarf and I'm Muslim. For the boys over here, I talk with them for homework and things.

It is interesting to note that, though Jordan and Yemen are both Arab-speaking countries, they differ in terms of dress code, food and dance. Jordan is more westernised than Yemen. The last wife of the late King Hussein of Jordan was the US-born Queen Noor of Syrian, English and Swedish descent, while his second wife, Princess Muna (mother of the current king, Abdullah II), was born in Britain. And the present queen of Jordan, Kuwaiti-born Queen Rania is seen dressed in western clothing. But Yemen still remains conservative. Most Yemeni women wear the black burqa and the niqab. In the US too, where there is a Yemeni concentration, young girls can be seen wearing the burqa and the niqab. Unfortunately, the cultural practice of honour killing occurs in both countries. ${ }^{47}$ Honour killings are mostly carried out by brothers or fathers of women who have had sex outside marriage or run away from home with their lovers.

\section{Cultural casualties?}

The practice of arranging the marriage of Muslim daughters at an early age is still carried out by some first-generation immigrants residing in the West, irrespective of their ethnic background. Some researchers such as Fauzia Ahmad and Nazli Kibria have found that the concepts of izzat and sharam play a major role in South Asian Muslim communities in Britain and the USA. Some immigrant parents assume that if they do not arrange the marriages of their daughters (and in some cases sons) to people of their same community, then the parents would be discredited by their community members. In many cases, arranged or forced marriages turn out to be successful, but sometimes arranged marriages end up in a divorce. ${ }^{48}$

In this study, I found that the casualties of arranged marriages were not only confined to young South Asian Muslims; they were across the board. For example, US-born Zohra (30, US born of Palestinian background, national identity: Muslim American) was married to her cousin in Palestine at the age of sixteen, but this arrangement ended in a divorce. Zohra said:

I could not click with him. He has the mentality of the Middle Eastern [people] and I was grown up here so it was hard for us even after ten years to click together.

And I tried to make the best out of it [our marriage] and I tried to make him more 
civilised because he never went to school and it was hard for him to accept that I do go to school. He wanted me to stay home and cook and clean and that's it. But honestly I have more energy to deliver to my community and I wanted to support myself and ... and you know he wasn't okay with it ... so I could not [be] surrounded [by] his ignorance ... some of them get married just for American citizenship. (Interview, New York, February 2010)

Another participant, US-born Zainab (28, Palestinian, national identity: Arab American), spoke of identity:

Going through everything I went through, growing up I was identified as Arab and not as American, and then when you realise when you're among Arabs you don't feel you're an Arab, you feel more American. So I guess American Muslims have a different identity. I'm like Arab American and I think it's a different identity than just being all American or all Arab.

Zainab was married at the age of eighteen to a Palestinian, but the marriage lasted only a few years. She said:

He wasn't willing to compromise at all. He said, 'If you disagree with me, then too bad.' You know, [he wanted me to] just keep my mouth closed or whatever and then it got really physical ... hostile. Well, I think he's a bit psycho. I think that being born and raised in a refugee camp might have affected him in a bad way.

Fortunately, both participants - Zohra and Zainab - had support from their family members, and were also employed in Islamic institutions.

\section{Post-9/11 casualties?}

After the $9 / 11$ tragedy, Muslim parents have been more inclined to anglicise their children's names, such as changing Mohammad to Martin, so that their children may be better accepted by the wider society. One of my Muslim acquaintances told me that her daughter's name was Mehjabin and she (the mother) pondered whether to anglicise the name because her daughter was bullied at school and taunted as 'bin Laden'.

A US-born woman of Pakistani background, Khojesta (30, an educator), thought that her marriage break-up was a casualty of the post-9/11 repercussions. Khojesta's parents had migrated to the USA in the 1960s, and since there was no Islamic school in her neighbourhood she attended a public school. She sometimes felt 'awkward' because she was the only Pakistani in the school, surrounded by 'a lot of Russians, a lot of Mexicans, and a lot of Irish'. Khojesta said that her parents 'were pretty strict but they also were very open minded about education; however, they didn't really encour- 
age us to have friends so we didn't socialise that much'. She recalled how her mother used to take her (and her siblings) to the public library every week and since then she has enjoyed reading. 'I read Wizard of $\mathrm{O} z$, I read Baby-Sitters Club, I read Sweet Valley High. I mean, you know, I read all of the famous [series]. Agatha Christie, I love her mysteries' (interview, New York, January 2010). Khojesta was married to an overseas-born Muslim man of Pakistani heritage, but the marriage ended in a divorce. Khojesta observed:

I don't think it's far fetched to say that 9/11 had a huge impact on my marriage. My husband was a private consultant, he depended on relationships in order to get his job, earn employment, so I felt like he kind of lost his identity because he felt like he had to stop being Muslim because it was a matter of paying the bills. It was only a single-income home so I think that affected us tremendously.

Khojesta said that her husband had 'tendencies towards being religious, but after $9 / 11$ he kind of felt like he couldn't reconcile his identity. Because of his accent it was even more difficult for him to be a part of western society.' After going through an unpleasant experience in her marriage, Khojesta was confused about her own identity when she said:

I still struggle as a second-generation American, but I'm starting to reconcile my Muslim identity with my American identity and on top of that my Pakistani identity ... Six years ago I would totally disconnect myself from being Pakistani or American.

\section{Young Muslim men}

Psychologist Amber Haque observed that for Muslim youths facing two cultures - western culture in school and Islamic culture at home - life can be very stressful and that can affect their mental health. For example, at public schools, students are generally expected to comply with cultural norms in dress code, food habits, socialisation and even proper English accent. Public holidays, such as Easter, Halloween and St Valentine's Day, do not exist in Islam, and Muslim children are often in a dilemma when their parents do not approve of participation in these events, such as eating Easter eggs, dressing-up for 'trick or treating' at Halloween, and going out on St Valentine's Day. Further complications arise among Muslims during adolescence when dating is the social norm for their non-Muslim friends. In order to fit in with their school social circle, young Muslims may wish to have friends of the opposite sex. But they are supposed to stay away from activities that entail mixing with the opposite gender. As with some other religious groups, selecting partners for marriage is a very serious issue for young Muslims because parents prefer them to marry within their own cultures. ${ }^{49}$ In this study some Muslim youths said that, even 
though they did not like their parents' decisions on some aspects of their life, such as marriage or career choice, they listened to them.

\section{It's my parents' terms}

A male participant, Akbar (22, US born of Bangladeshi background, national identity: Bengali American), said that he could not pursue his ambitions because of his parents' decision:

Actually to be honest the only reason I'm going in a science major and becoming a dentist is because of my parents, because I had no intention of doing this. I had a chance of working on BMW when I was sixteen. I was going to get hired and I was supposed to go to Germany and work for them but my parents denied it and I also had a spot at MIT but they wouldn't let me go so I'm stuck with this. (Interview, Maryland, March 2010)

In this context, the non-western 'collectivist self' came to the fore. Through the 'collectivist self' individuals may enhance their family's social standing, meet the expectations of family members and feel indebted to their parents, who have made enormous sacrifices to raise and support them. Sometimes quite reluctantly, young people such as Akbar abide by their parents' decisions. But this is another cultural practice that is not exclusive to Muslims. For example, a Chinese student's desire to achieve academically is likely to be socially rooted, and not to be concerned with a 'me' personality. ${ }^{50}$

\section{Cultural dilemmas}

Several participants in this study expressed cultural dilemmas. For example, Sharukh Ali (male, 18, US born of Pakistani heritage, national identity: Pakistani American) is the younger of two brothers in his family with a father who had to retire seventeen years ago because of his severe health condition. His mother was also sick but she had to look after the family. Sharukh Ali said, 'My older brother is into drugs. So my mother is very stressed out. She wants to get me married' (interview, Michigan, May 2010). When I asked Sharukh Ali how his brother gets money for the drugs, he replied, 'Sometimes he does construction work.' When I asked about the drugs and how they operate, Sharukh Ali replied:

My brother smokes marijuana. Marijuana is a very advanced drug. I mean it started off a long time ago, but nowadays there's new ways of developing, of getting high. It's not basically the marijuana, it's the chemical in it, THC, that will get somebody high, and there are different standards of weed, marijuana. I mean just the names that it's given you can tell it's been around. I mean you can call it marijuana, cannabis, 
reefer, joint, blunt, spliff, doobie and ... Marijuana is not really as bad as alcohol is, because marijuana, it just tends to like make people forget stuff. Like they get high, their eyes get low, they'll get red, you can smell it on them, they'll laugh sometimes. It'll make people really, really hungry. But gradually, it kills brain cells in your body.

When I asked Sharukh Ali if it was popular among the young people, he replied, 'It's very, very common, yeah. A smoke but then again is that it is just a cigarette in disguise. It's basically a cigarette with a flavour.' When asked how young people get the drugs, Sharukh replied, 'There are illegal spots. Around here you're not supposed to be selling, but just now there's a system, there's every way to corrupt the system.'

Speaking about his leisure time activities, Sharukh Ali said:

I just study and play basketball. I listen to rap just to hear what they got to say. Because I mean I got a brother that is also kind of living a rapper's lifestyle and it's kind of interesting to hear their lyrics and see what will cause them to do something like that, or kind of give me idea how to help my brother. And my brother is not really bad, just he doesn't like to listen. He wants to have things his own way, and buy drugs. Like he doesn't pop pills. He doesn’t drink. He just smokes a lot of weed.

Sharukh Ali's brother was perhaps a casualty of being the oldest son of firstgeneration immigrants. Due to their low education levels and lack of English language skills, immigrant parents use their children as interpreters, which can be stressful for the children. Also, young immigrants' relocation and acculturation can lead them to hang out with the wrong crowd. In this case, Sharukh Ali was trying to compensate for his older brother by agreeing to get married at a very young age (even before pursuing his career):

I'm going to Pakistan this summer. I'm going to choose a wife, and I'm going to get engaged. Then I'm going to get to know her, so it's not a complete stranger to marry, and hopefully it'll be according to a Muslim tradition and engaged, marriage ...

When I asked Sharukh Ali, 'So do you think you will have a good adjustment with your wife, who will have a different culture?' he replied:

No, I'm going to get really along with her 'cos I think that I understand people. I don't really, like, go for looks and I think it's all about the personality. And just get married, make my dad happy. Let him see at least one of his kids standing on his two feet before he passes away. Give him a little something in life.

The drug problem is not exclusive to young Muslims. It is a problem for youths of all backgrounds. Adolescent drug use is a serious public health concern in the United States, especially among high-risk ethnic and racial groups. In 
2005, 26.5 per cent of youths aged 14-15 years and 41.9 per cent of youths aged 16-17 years had tried an illicit drug. The prevalence of adolescent substance use has been found to be particularly high among Hispanic and Latino youths, ${ }^{51}$ and immigrant youths are also susceptible to the use of illicit drugs. For one reason or another, they tend to ignore parental authority and discipline and thereby become more prone to substance use. The young people also want to 'fit in' with the wider society and that could lead to further tension with their parents. The substance use could be an individual choice, but anti-social peer pressure is another factor in the use of drugs among immigrant youths. ${ }^{52}$

Asian Americans, such as Filipinos, Chinese, Koreans, Vietnamese, Indonesians, Indians and Pakistanis, might use alcohol or illicit drugs for several reasons. First, in adopting the host culture some young Asian immigrants resist the overly protective nature of their parents and succumb to the pressure of acculturation from the host society. As Molly Moloney et al. observed, 'Caught between two competing and often conflicting cultures - their own or their parents' "traditional" culture and their newly adopted culture - young immigrants may turn to drugs and alcohol as "coping mechanisms" to reconcile potentially conflicting pressures. ${ }^{53}$ Furthermore, in some cases immigrant parents face economic hardship and take full-time jobs, which do not allow them to monitor how their children are faring in school. Another factor is loneliness, anxiety and depression along with the inability to fit in to the host culture. ${ }^{54}$

In the midst of such social concerns, some Muslim parents (like some other non-Muslim groups) choose homeschooling for their children. In the next section, I examine the homeschooling system among Muslim families and consider whether it is helpful for social cohesion within the wider society.

\section{Muslim youths' homeschooling}

According to Priscilla Martinez, Muslim families are among the fastestgrowing homeschoolers in the United States. Martinez observes the following reasons why Muslim families choose homeschooling for their children:

- to provide a better education compared to public and private faith schools

- for special-needs children who require specific learning attention

- for flexible school attendance (if they need to spend time travelling)

- to save their children from bullies, drugs, gangs and guns. ${ }^{55}$

Homeschoolers have to follow the curriculum of the education board; however, Muslim families think that they can include more Islamic education through homeschooling. There are arguments for and against homeschooling. Parents in favour argue that through homeschooling their children learn unique Islamic values and ethics. It also enables their children to socialise 
more with the Muslim community and the wider society through volunteering and community services, activities at local libraries, recreation at the YMCA, sporting activities, field trips and boy/girl scout programmes, and in mosques. Those against homeschooling claim it prevents children from socialising and integrating with the wider society. They argue that children are slower to develop their social skills and social negotiation skills when confronted with major events outside their cultural space. There are other challenges such as bullying in regular schools. By keeping children in isolation (homeschools), the children do not learn to cope with challenges. ${ }^{56}$

Through my fieldwork, I met one male Muslim university student who was involved with the Muslim Students' Association in a university. He was not interested in participating in my survey, saying, 'I haven't much to say because I was homeschooled.' By this he either implied he was not aware of happenings in the wider society, or simply that he was not confident enough to speak up. Later, I interviewed an educator of homeschooled children who spoke about the pros and cons of the system. Ayub, aged twenty-five, a Muslim convert of Caucasian American background (national identity: Muslim American), had a Master's in special education and a degree in education. He served students in both public schools and private tutoring and had this to say about homeschooling:

I worked to help a few families with homeschooling. They were not happy with the public schools and there was no private school that was within distance.

We based our homeschooling on a curriculum that was available. I found it for the particular situation we were in to be a tremendous success because most of the students, you know, had completed two grade levels in one year. So they were moving at a very fast pace because it was an individualised education. (Interview, Massachusetts, December 2009)

Ayub continued with his opinion:

The reason big schools don't pursue individualised education is because it costs a lot of money to do it. This particular family had the money and resources to hire certified and licensed teachers ... I wouldn't say it is good or bad, it's really a case-bycase basis. I've seen it really work well, and I've seen it really not do so well.

Ayub observed that in a homeschool setting there needed to be effort from all sides: the student's learning attitude, the parents' expectations and the educator's efforts. On its social aspects, Ayub said, 'Interactions with peers - they get plenty of it during most of the day, they have activities scheduled throughout the day as a school ... with groups, YMCA, boy scouts, swimming teams, you name it.' On communication, Ayub observed: 
Interaction within the class is always dynamic. We have a discussion on a topic and hear other people's opinions and ideas but it is somewhat lost in homeschooling. So there's big plusses and minuses. I'm pretty neutral on the homeschooling issue.

Ayub also spoke about the social, spiritual, emotional, academic and physical development of young home-schooled children:

I've seen homeschooling do it very well and very poorly, and I've seen plenty of public schools and private schools do it very well and very poorly. I don't think it's the concept itself, I think it's how it's done.

From an educator's point of view, Ayub has explained the positive and negative aspects of homeschooling. Homeschooling is also popular with people of other ethnic, racial and religious backgrounds. From my research point of view, however, homeschooling can hinder Muslim youths' development of their bicultural skills. In the current geopolitical environment, where Muslims are considered as the 'other' by a certain section of the wider society, it is important that youths interact with the wider society through debate and sport. Interaction and integration are more likely to occur through regular schools.

\section{Conclusion}

In this chapter, I have examined several issues young Muslims face in the course of their development. The participants of this study were mostly second-generation Muslims who were endeavouring to cope with their parents' cultural expectations and to 'fit in' with the wider society. Sometimes the cultural expectations from their parents and the wider society were discrepant. Their parents were mostly first-generation Muslims living in a diaspora, and some hoped to return to their 'home' one day. Most wanted their children to adopt the parents' ethnic culture. On the other hand, the parents needed help from their children to improve their language skills. Often parents struggled to find jobs and were not fitting into the host society. In the face of these tensions second-generation Muslims were trying to be a part of the host society. In the entire process of enculturation and acculturation, it is obvious that the young people need to acquire bicultural skills so that they can be competent in both cultures. A balance between the two cultures is possible if parents allow and even encourage their children to be a part of the host society through education, sport and socialisation with their non-Muslim peers.

There are some issues within the Muslim community, such as Sunni-Shia relations and patriarchal tendencies, that need to be addressed for the sake of a cohesive society. Of course, some Muslim women unfortunately bear the oppression of men but overall their strong family foundation is adding to the 
mosaic of American society. The wider society should recognise the importance of cultural diversity and encourage immigrants to retain their languages and those aspects of their culture that are lawful. And surely the host nation would enhance its international standing by allowing Muslim women their choice of attire.

\section{Notes}

1. Stuart Hall, 'The Question of Cultural Identity', in The Polity Reader in Cultural Theory (Cambridge: Polity Press, 1994), p. 122; Anita Jones Thomas and Sara E. Schwarzbaum, Culture and Identity: Life Stories for Counselors and Therapists (Thousand Oaks, CA: Sage, 2006), p. 5.

2. David Matsumoto and Linda Juang, Culture and Psychology, 3rd edn (Belmont, CA: Thomson Wadsworth, 2004), p. 301.

3. Ibid., pp. 134, 156.

4. Ibid., p. 155.

5. Ibid. pp. 135-54.

6. Hazel R. Markus and Shinobu Kitayama, 'Culture and the self: implications for cognition, emotion, and motivation', Psychological Review 98 (1991), pp. 224-53; Matsumoto and Juang, Culture and Psychology, pp. 301-2.

7. Alberto Melucci, 'Identity and Difference in a Globalized World', in Pnina Werbner and Tariq Modood (eds), Debating Cultural Hybridity: Multi-cultural Identities and the Politics of Anti-racism (London: Zed, 1997), pp. 58-69; Gary S. Gregg, Culture and Identity in a Muslim Society (Oxford: Oxford University Press, 2007).

8. Gregg, Culture and Identity in a Muslim Society, p. 19.

9. Melucci, 'Identity and Difference in a Globalized World', p. 64.

10. Ibid. p. 65.

11. Seyyed Hossein Nasr, The Heart of Islam: Enduring Values for Humanity (San Francisco: HarperSanFrancisco, 2002), pp. 65-6.

12. Ibid.

13. Ibid. pp. 68-70; see also Jane I. Smith, Islam in America, 2nd edn (New York: Columbia University Press, 2010), p. 119.

14. Jocelyne Cesari, When Islam and Democracy Meet: Muslims in Europe and in the United States (New York: Palgrave Macmillan, 2004), p. 95.

15. Haneef James Oliver, The 'Wahhabi' Myth: Dispelling Prevalent Fallacies and the Fictitious Link with Bin Laden, 2nd edn (Toronto: TROID, 2004), p. 62.

16. Cesari, When Islam and Democracy Meet, p. 51; Shaykh Muhammad Hisham Kabbani, Illuminations: Compiled Lectures on Shari'ah and Tasawwuf (Fenton, MI: Islamic Supreme Council of America, 2007), pp. 24-5.

17. Cited in Kabbani, Illuminations, p. 23.

18. Sayed Moustafa Al-Qazwini, Inquiries about Shi'a Islam (Costa Mesa, CA: Islamic Educational Center of Orange County, 2000), pp. 4-9. 
19. Nasr, The Heart of Islam, pp. 70-2; see also Smith, Islam in America, pp. 30-1.

20. Liyakat Nathani Takim, Shi'ism in America (New York: New York University Press, 2009), p. 90.

21. For further details on separate theological schools of thought among Muslims in the Indian subcontinent, see Nahid Afrose Kabir, Young British Muslims: Identity, Culture, Politics and the Media (Edinburgh: Edinburgh University Press, 2010), p. 60 .

22. Takim, Shi'ism in America, p. 23; Smith, Islam in America, p. 63.

23. Takim, Shi ism in America, pp. 133-6.

24. Ibid., pp. 119-20.

25. See also Takim, Shi ism in America, pp. 140-1.

26. Smith, Islam in America, pp. 78-103; see also Herbert Berg, Elijah Muhammad and Islam (New York: New York University Press, 2009).

27. Smith, Islam in America, p. 84.

28. Ibid. p. 91.

29. Ibid., p. 96; see also Takim, Shi'ism in America, p. 197.

30. Jamillah Karim, American Muslim Women: Negotiating Race, Class and Gender within the Ummah (New York: New York University Press, 2009), p. 32.

31. Anna Bowers, 'The Search for Justice: Islamic Pedagogy and Inmate Rehabilitation', in Yvonne Y. Haddad, Farid Senzai and Jane I. Smith (eds), Educating the Muslims of America (Oxford: Oxford University Press, 2009), pp. 179-207, see pp. 184-5.

32. Ibid.

33. 'Gallup survey finds Muslims are younger, more racially diverse', Christian Century, 21 April 2009, pp. 18-19.

34. Muslim Americans: No Signs of Growth in Alienation or Support for Extremism, (Washington, DC: Pew Research Center 2011), http://www.people-press.org/files/ legacy-pdf/Muslim-American-Report.pdf, accessed 15 May 2012.

35. Ibid., p. 18.

36. Ibid., p. 17.

37. Ibid.

38. Jobs are often classified as non-professional or professional, though the distinction between the two can be vague. Jobs are considered professional if they require specialised knowledge and advanced skills in a particular area. Teachers, engineers and doctors are all considered professionals. Most jobs classified as professional by the US Bureau of Labor Statistics require an associate or higher degree. Nonprofessional jobs do not require a college degree and usually provide on-the-job training. See Susan Stopper, 'Non-professional vs. professional jobs', eHow website, http://www.ehow.com/info_8140675_nonprofessional-vs-professionaljobs.html, accessed 15 May 2012.

39. See Randa Abdel-Fattah, Does My Head Look Big in This? (Sydney: Pan Macmillan Australia, 2005).

40. Further discussion on education and employment can be found in Chapter 6 .

41. Asra Q. Nomani, Standing Alone at Mecca: An American Woman's Struggle for 
the Soul of Islam (San Francisco: HarperSanFrancisco, 2005); see Smith, Islam in America, p. 186.

42. Smith, Islam in America, p. 136.

43. Ibid. p. 137.

44. See also Sondos M. S. Islam and Carl Anderson Johnson, 'Correlates of Smoking Behavior among Muslim Arab-American Adolescents', Ethnicity and Health 8:4 (2003), p. 322.

45. I have discussed mosques' restrictions and women in my previous work. See Kabir, Young British Muslims, pp. 62-4.

46. Yvonne Yazbeck Haddad, Jane I. Smith and Kathleen M. Moore, Muslim Women in America: The Challenges of Islamic Identity Today (New York: Oxford University Press, 2006), p. 17. See also Nazli Kibria, Muslims in Motion: Islam and National Identity in the Bangladeshi Diaspora (New Brunswick, NJ: Rutgers University Press, 2011), p. 66.

47. “"Honour killings” laws blocked', BBC News website, 8 September 2003, http:// news.bbc.co.uk/2/hi/middle_east/3088828.stm, accessed 16 May 2012.

48. Fauzia Ahmad, 'The Scandal of “Arranged Marriages" and the Pathologisation of BrAsian Families', in N. Ali, V. S. Karla and S. Sayyid (eds), A Postcolonial People: South Asians in Britain (New York: Columbia University Press, 2008), pp. 272-90; Kibria, Muslims in Motion, p. 72; Kabir, Young British Muslims, pp. 66-71.

49. Amber Haque, 'Religion and Mental Health: The Case of American Muslims', Journal of Religion and Health 43 (2004), pp. 45-55.

50. Matsumoto and Juang, Culture and Psychology, p. 307.

51. Karla D. Wagner, Anamara Ritt-Olson, Daniel W. Soto, Yaneth L. Rodriguez, Lourdes Baezconde-Garbanati and Jennifer B. Unger, 'The Role of Acculturation, Parenting, and Family in Hispanic/Latino Adolescent Substance Use: Findings from a Qualitative Analysis', Journal of Ethnicity in Substance Abuse 7:3 (2008), pp. 304-27.

52 Ibid.

53. Molly Moloney, Geoffrey Hunt and Kristen Evans, 'Asian American Identity and Drug Consumption: From Acculturation to Normalization', Journal of Ethnicity in Substance Use 7:4 (2008), pp. 376-403, see p. 379.

54. Ibid., p. 388.

55. Priscilla Martinez, 'Muslim Homeschooling', in Haddad, Senzai and Smith (eds), Educating the Muslims of America, p. 110.

56. Ibid., pp. 115-20. 